\title{
AVAILABLE Cd CONTENT OF SALT-AFFECTED AND NORMAL SOILS OF HALASTRA-KALOHORI AREA
}

\author{
TH. MATSI $I^{1, *}$ \\ E.G. HATZIGIANNAKIS ${ }^{2}$ \\ G.K. ARAMPATZIS ${ }^{2}$ \\ A.G. PANORAS ${ }^{2}$
}

\author{
${ }^{1}$ Soil Science Laboratory, School of Agriculture \\ Aristotle University of Thessaloniki \\ 54124, Thessaloniki, Greece \\ ${ }^{2}$ Land Reclamation Institute, NAGREF \\ 57400, Sindos, Greece
}

*to whom all correspondence should be addressed: e-mail: thmatsi@agro.auth.gr
Received: 02/02/07

Accepted: 02/04/07

\begin{abstract}
A survey was conducted in order to evaluate the levels of available (DTPA extractable) Cd in salt affected and normal soils of Halastra-Kalohori area, located in N. Greece. In this area, phosphogypsum (PG) (a byproduct of $P$ fertilizer industry, occasionally enriched with $C d$ ) has been used as amendment for the salt affected soils, for at least 20 years until 2000 . The area is about $6300 \mathrm{ha}$, and 4500 ha were cultivated with rice. Soil samples were collected from 632 points and four depths $(0-25,25-50,50-75,75-100 \mathrm{~cm})$, during 2003 and 2004. All soil samples were analyzed for particle size distribution, $\mathrm{pH}$ in the paste, electrical conductivity of the saturation extract $\left(E_{\mathrm{e}}\right)$, water soluble $\mathrm{Na}, \mathrm{Ca}$ and $\mathrm{Mg}$, cation exchange capacity (CEC) and exchangeable $\mathrm{Na}$. The sodium absorption ratio (SAR) and exchangeable sodium percentage (ESP) were calculated. The 632 soils were characterized as salt affected (saline, saline-sodic, sodic) or normal, using the values of EC, SAR and ESP, and $\mathrm{pH}$. In addition, the soil samples collected from the 0-25 and 25-50 cm depths were analyzed for DTPA extractable $\mathrm{Cd}$ and Olsen P. All soils were alkaline in reaction. In most of the cases, concentrations of DTPA extractable $\mathrm{Cd}$ in the $0-25 \mathrm{~cm}$ depth were higher than in the 25-50 $\mathrm{cm}$ depth and the mean values differed significantly $(p<0.001)$. For both depths, concentrations of DTPA extractable Cd were higher for salt affected than normal soils and the mean values within each depth differed significantly $(p<0.001)$. This could be attributed to the use of PG as soil amendment. In addition, a significant and positive relationship was obtained for DTPA extractable Cd and $\mathrm{EC}_{\mathrm{e}}(\mathrm{r}=0.31, p<0.001)$. However, DTPA extractable $\mathrm{Cd}$ ranged at levels similar or lower to those reported in the literature for cultivated soils with high $\mathrm{P}$ fertilization, in almost all cases. This is something to be expected since $80 \%$ of all soils were sufficient or over-fertilized with $P$ (Olsen $P>15 \mathrm{mg} \mathrm{kg}^{-1}$ ). A significant and positive relationship, obtained for DTPA extractable Cd and Olsen $\mathrm{P}(r=0.47, p<0.001)$, supported the conclusion that the source of DTPA extractable $\mathrm{Cd}$ could also be traced to the long-term P fertilization. Concentrations of DTPA extractable Cd were significantly $(p<0.001)$ correlated with certain soil properties that affect $\mathrm{Cd}$ availability to plants, such as $\mathrm{pH}(r=-0.26)$, clay content $(r=0.22)$ and CEC $(r=0.26)$.
\end{abstract}

KEYWORDS: Cadmium, phosphogypsum, salt affected soils.

\section{INTRODUCTION}

Cadmium accumulates in soils through weathering of soil parent material, atmospheric deposition from industrial activities, disposal of wastes (sewage sludge, animal manures and industrial byproducts) and soil application of fertilizers (especially phosphates, lime and agrochemicals). Certain soil properties influence soil $\mathrm{Cd}$ availability to plants. Soil pH seems to be the major factor that affects $\mathrm{Cd}$ availability and in general, $\mathrm{Cd}$ becomes more readily 
available under acidic conditions. Other soil properties, that affect $\mathrm{Cd}$ availability, are clay and organic matter content, cation exchange capacity (CEC), Fe, Mn and Al oxides and redox potential (Alloway, 1995).

Phosphogypsum (PG) is a byproduct of wet acid production of phosphoric acid from phosphate rocks. It is essentially hydrated $\mathrm{CaSO}_{4}$, highly acidic in reaction due to $\mathrm{H}_{2} \mathrm{SO}_{4}$ residue, with small proportions of $\mathrm{P}, \mathrm{F}, \mathrm{Si}, \mathrm{Al}, \mathrm{Fe}$, several minor elements, heavy metals, (especially $\mathrm{Cd}$ ) and radionuclides (especially ${ }^{226} \mathrm{Ra}$ ). Phosphogypsum is used as a soil amendment for several agronomic purposes, such as the reclamation of saline-sodic and sodic soils, although its heavy metal and radionuclide content give rise to environmental concerns. However, the risk of environmental contamination due to soil application of PG seems to be negligible, if the recommended rates for agronomic use of PG (no more than 30 $\mathrm{Mg} \mathrm{ha}^{-1}$ ) are followed (Alcordo and Rechcigl, 1993).

In Halastra-Kalohori area (N. Greece), salt affected soils have been formed (Panoras et al., 2005), mainly because the area is near to the sea. In addition, the irrational use of irrigation water and the insufficient drainage are also significant factors, contributing to the continuation of this situation. Phosphogypsum, derived from a fertilizer industry operating in the particular area, has been used as a soil amendment for at least 20 years, until 2000. Since no official supervision on PG use was exercised, the farmers were applying PG not only to saline-sodic or sodic soils, for which is recommended, but also to saline soils, and occasionally at amounts that greatly exceeded the common rates for agronomic purposes.

Thus, the main objectives of the present work were to provide information about the available (DTPA extractable) Cd content of salt affected and normal soils of Halastra-Kalohori area. In addition, possible relations between certain physical and chemical properties and available $\mathrm{Cd}$ of the soils were investigated.

\section{MATERIALS AND METHODS}

Halastra-Kalohori area is located in N. Greece and is about 6300 ha. Soil samples were collected from 632 points (Figure 1) and from four depths (0-25, 25-50, 50-75 and 75-100 $\mathrm{cm}$ ), during 2003 and 2004 . The sampling points were selected on a grid basis and each point represented about 10 ha. The main part of the area (4500 ha) was cultivated with rice, while the rest was cultivated with cotton, maize and alfalfa.

The soil samples were air-dried, passed through a 2-mm sieve and analyzed for some physical and chemical properties (Table 1). Specifically, particle size distribution was determined by the hydrometer method (Bouyoucos, 1962) and soil pH was measured in the saturated paste. Soil electrical conductivity $\left(\mathrm{EC}_{\mathrm{e}}\right)$ and water soluble $\mathrm{Na}$ (by Flame Emission Spectroscopy), $\mathrm{Ca}$ and $\mathrm{Mg}$ (by Atomic Absorption Spectroscopy) were determined in the saturation extract (Rhoades, 1996). Exchangeable $\mathrm{Na}$ was extracted using $1 \mathrm{~N} \mathrm{CH}_{3} \mathrm{COONH}_{4}$, $\mathrm{pH}=8.5$ (Thomas, 1982) and determined by Flame Emission Spectroscopy. Cation exchange capacity (CEC) was determined, using $\mathrm{CH}_{3} \mathrm{COONa}, 1 \mathrm{~N}, \mathrm{pH}=8.2$, as saturating solution and $\mathrm{CH}_{3} \mathrm{COONH}_{4}, 1 \mathrm{~N}, \mathrm{pH}=7$, as extracting solution (Chapman, 1965).

Table 1. Some physicochemical properties of the soils

\begin{tabular}{|c|c|c|c|c|}
\hline \multirow[t]{3}{*}{ Soils } & \multicolumn{2}{|c|}{ Clay $\left(\mathrm{g} \mathrm{kg}^{-1}\right)$} & \multicolumn{2}{|c|}{ CEC $\left(\mathrm{cmol}_{\mathrm{c}} \mathrm{kg}^{-1}\right)$} \\
\hline & \multicolumn{2}{|c|}{$293^{\dagger} \pm 168^{\ddagger}$} & \multicolumn{2}{|c|}{$20 \pm 10$} \\
\hline & $\mathrm{pH}$ & $\mathrm{EC}_{\mathrm{e}}\left(\mathrm{mS} \mathrm{cm} \mathrm{cm}^{-1}\right)$ & SAR & ESP \\
\hline Salt affected & $7.9 \pm 0.3$ & $4.1 \pm 2.2$ & $9.8 \pm 8.8$ & $10.9 \pm 8.6$ \\
\hline Normal & $8.1 \pm 0.3$ & $1.1 \pm 0.7$ & $2.6 \pm 2.8$ & $3.0 \pm 3.6$ \\
\hline
\end{tabular}

Sodium absorption ratio (SAR) was calculated from water soluble $\mathrm{Na}, \mathrm{Ca}$ and $\mathrm{Mg}$ and exchangeable sodium percentage (ESP) was calculated from exchangeable $\mathrm{Na}$ and CEC. 
Using $\mathrm{EC}_{\mathrm{e}}, \mathrm{SAR}$ and $\mathrm{ESP}$, and $\mathrm{pH}$, soils were characterized as salt affected (saline, saline-sodic, sodic) or normal soils. The critical limits were $E C_{e} \cong 2 \mathrm{mS} \mathrm{cm}^{-1}$ (for sensitive crops), $\mathrm{SAR} \cong 13$ and $\mathrm{ESP} \cong 15$, and $\mathrm{pH} \cong 8.5$, and the characterization is shown in Table 2 (Brady and Weil, 2002). Soils with values, of the previously mentioned chemical properties, below the critical limits in the whole soil profile or in the $0-75 \mathrm{~cm}$ depth were characterized as normal.

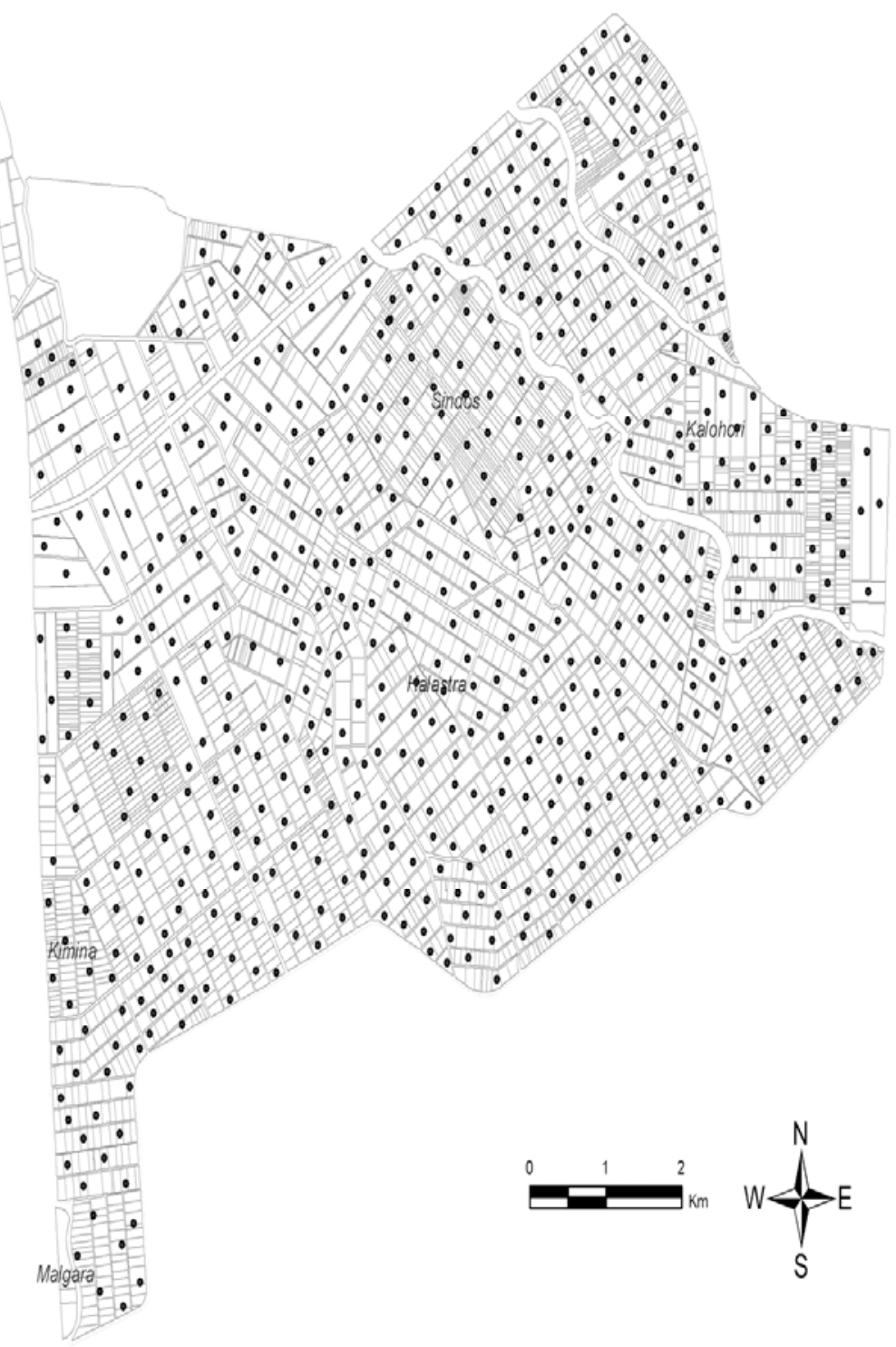

Figure 1. Soil sample points from Halastra-Kalohori area

Table 2. Characterization of the soils as salt affected or normal

\begin{tabular}{lcccc}
\hline & \multicolumn{3}{c}{ Salt affected } & Normal \\
\cline { 2 - 4 } & Saline & Saline-Sodic & Sodic & \\
\hline EC $_{\mathrm{e}}\left(\mathrm{mS} \mathrm{cm}^{-1}\right)$ & $\geq 2$ & $\geq 2$ & $<2$ & $<2$ \\
$\mathrm{SAR}$ & $<13$ & $\geq 13$ & $\geq 13$ & $<13$ \\
$\mathrm{ESP}$ & $<15$ & $\geq 15$ & $\geq 15$ & $<15$ \\
$\mathrm{pH}$ & $<8.5$ & $<8.5$ & $\geq 8.5$ & $<8.5$ \\
\hline
\end{tabular}


The soil samples collected from the depths $0-25$ and $25-50 \mathrm{~cm}$ were also analyzed for available $\mathrm{Cd}$ and P. Specifically, available Cd was extracted using DTPA (0.005M DTPA, $0.1 \mathrm{M}$ TEA and $0.01 \mathrm{M} \mathrm{CaCl}, \mathrm{pH}=7.3$ ) and determined by Atomic Absorption Spectroscopy (Lindsay and Norvell, 1978). Available P (Olsen P) was extracted using $0.5 \mathrm{M} \mathrm{NaHCO}, \mathrm{pH}=8.5$ and determined by the molybdenum blue-ascorbic acid method (Olsen and Sommers, 1982).

One way analysis of variance (ANOVA) was conducted to detect significant differences in respect to DTPA extractable Cd content among depths and among salt affected and normal soils within each depth. In addition, correlation analysis was used to relate DTPA extractable $\mathrm{Cd}$ to other soil characteristics, such as $\mathrm{pH}$, clay content, $\mathrm{CEC}, \mathrm{EC}_{\mathrm{e}}$ and Olsen P content.

\section{RESULTS AND DISCUSSION}

The soils differed in their physicochemical properties, but all were alkaline in reaction (Table 1). The majority, of the 632 soils analyzed, was loamy in texture. As far as salt affected soils it concerns, 177 soils ( $28 \%$ of all soils studied) were saline or saline-sodic.

Mean values of DTPA extractable Cd concentration were $0.23 \pm 0.12$ and $0.17 \pm 0.10 \mathrm{mg} \mathrm{kg}^{-1}$, for the depths $0-25$ and $25-50 \mathrm{~cm}$, respectively and differed significantly $(p<0.001)$. In most of the cases, concentrations of DTPA extractable $\mathrm{Cd}$ in the 0-25 cm depth were higher than in the $25-50 \mathrm{~cm}$ depth, as it is evident from Figure 2. This is in agreement with other researchers' findings. It is reported that within the soil profile, $\mathrm{Cd}$ is usually accumulated in the surface horizon, since this zone has the highest organic matter content and consequently high metal retention capacity. However, unlike other heavy metals, Cd has a tendency to move down the profile, with the extent and rate of this movement depending on various soil and site factors (Alloway, 1995).

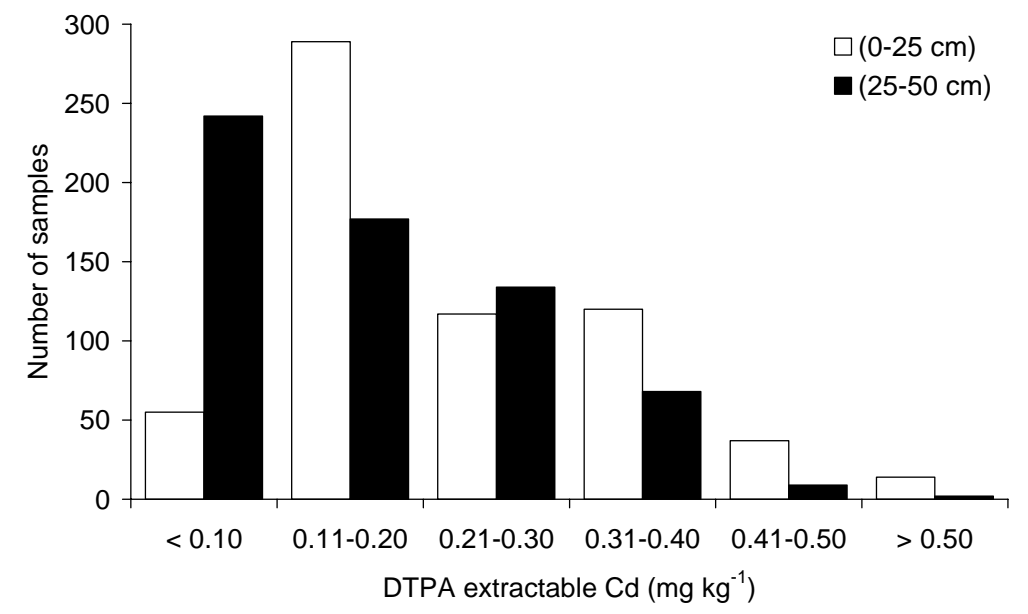

Figure 2. Distribution of all soils among 6 classes of DTPA extractable Cd concentration

Figure 3 shows that DTPA extractable Cd concentrations of the salt affected soils ranged at levels higher than the normal soils, for both depths, and a similar trend was obtained for the mean values. Specifically, for the depth $0-25 \mathrm{~cm}$, average Cd concentration for the salt affected soils was $0.29 \pm 0.14 \mathrm{mg} \mathrm{kg}^{-1}$ and it was significantly higher than the respective $0.21 \pm 0.11 \mathrm{mg} \mathrm{kg}^{-1}$ of the normal soils $(p<0.001)$. For the depth $25-50 \mathrm{~cm}$, average $\mathrm{Cd}$ concentration was $0.22 \pm 0.11 \mathrm{mg} \mathrm{kg}^{-1}$, and it was significantly higher than the respective $0.15 \pm 0.10 \mathrm{mg} \mathrm{kg}^{-1}$ of the normal soils $(p<0.001)$. This difference could be attributed to the use of PG as an amendment for the salt affected soils. In addition to the above, a significant and positive relationship was obtained for DTPA extractable $\mathrm{Cd}$ and $\mathrm{EC}_{\mathrm{e}}(r=0.31, p<0.001)$. 

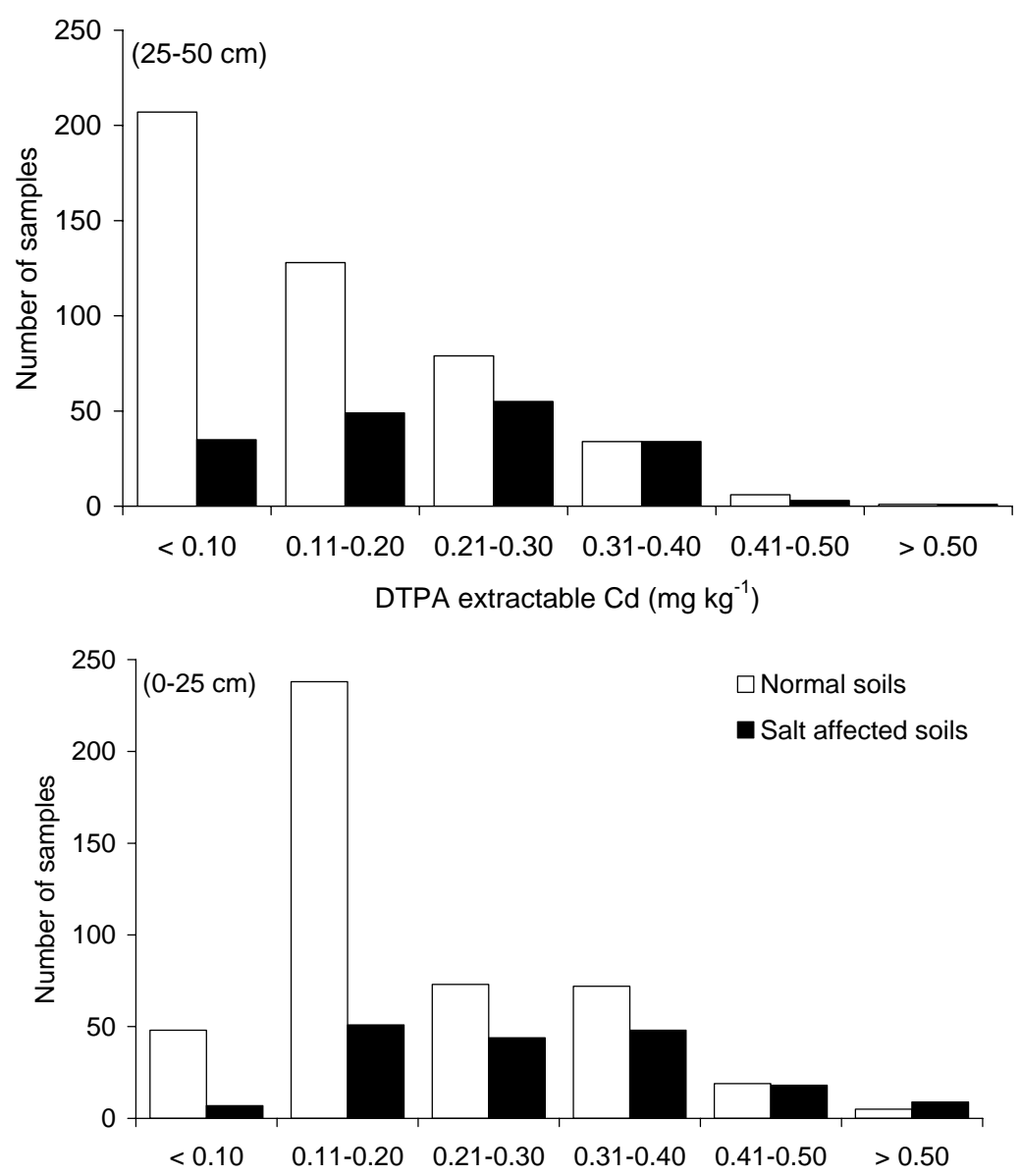

Figure 3. Distribution of normal and salt affected soils among 6 classes of DTPA extractable Cd concentration

However, relatively high concentrations of soil available $\mathrm{Cd}$, meaning at the range of $0.11-0.50 \mathrm{mg} \mathrm{kg}^{-1}$, are reported for cultivated soils with high $P$ fertilization (FAO, 1992). Consequently, for all soils studied, higher levels of DTPA extractable $\mathrm{Cd}$ concentrations could be also due to the long-term $P$ fertilization. As it was judged from Olsen $P$ concentrations, only $20 \%$ of the soils were deficient in $\mathrm{P}$ (Olsen $\mathrm{P}<15 \mathrm{mg} \mathrm{kg}^{-1}$ ), whereas $45 \%$ of the soils were over-fertilized. In addition to the above, a significant and positive relationship was obtained for DTPA extractable Cd and Olsen P $(r=0.47, p<0.001)$. In agreement with these findings, it is reported that, the effect of soil available $\mathrm{P}$ along with $\mathrm{pH}$ on the $\mathrm{Cd}$ uptake by spring wheat grains was significant and greater than other heavy metals (Nan et al., 2002). On the contrary to the above, based on data from eight long-term fertilization experiments with wheat, it is reported that, in general long-term $\mathrm{N}$ or $\mathrm{P}$ fertilization did not increase grain Cd or soil Cd (Gavi et al., 1997).

In agreement with other researchers findings (Alloway, 1995; Chen et al., 1999), concentrations of DTPA extractable Cd were significantly $(p<0.001)$ correlated with soil properties that affect soil $\mathrm{Cd}$ availability, such as $\mathrm{pH}(r=-0.26)$, clay content $(r=0.22)$ and CEC $(r=0.26)$.

\section{CONCLUSIONS}

In almost all cases of the 632 (normal and salt affected) soils of Halastra-Kalohori area analyzed, soil available $\mathrm{Cd}$ ranged at levels similar or lower to those reported in the literature for cultivated soils with high P fertilization. This is something to be expected, since $80 \%$ of all soils were efficient or over-fertilized with P. Relatively higher soil available Cd levels, obtained 
for the salt affected soils, could be attributed to the use of PG as an amendment. However, even in this case, the long-term $P$ fertilization could also be a possible source of soil $\mathrm{Cd}$. Since all soils of the studied area are alkaline in reaction, the availability of soil $\mathrm{Cd}$ is expected to be reduced.

\section{REFERENCES}

Alcordo I.S. and Rechcigl J.E. (1993) Phosphogypsum in agriculture: A review, Advances in Agronomy, 49, 55-118.

Alloway B.J. (1995) Heavy Metals in Soils, Blackie Academic and Professional, London.

Bouyoucos G.J. (1962) Hydrometer method improved for making particle size analyses of soils, Agronomy Journal, 54, 464-465.

Brady N.C. and Weil R.R. (2002) The Nature and Properties of Soils, Prentice Hall, New Jersey.

Chapman H.D. (1965) Cation exchange capacity, In: Methods of Soil Analysis: Part 2 - Chemical and Microbiological Properties, Black C.A. (ed.), ASA, SSSA, Madison, WI.

Chen M., Ma L.Q. and Harris W.G. (1999) Baseline concentrations of 15 trace elements in Florida surface soils, Journal of Environmental Quality, 28, 1173-1181.

FAO (1992) Status of cadmium, lead, cobalt and selenium in soils and plants of thirty countries, FAO Soils Bulletin, 65, 1-195.

Gavi F., Basta N.T. and Raun W.R. (1997) Wheat grain cadmium as affected by long-term fertilization and soil acidity, Journal of Environmental Quality, 26, 265-271.

Lindsay W.L. and Norvell W.A. (1978) Development of a DTPA test for zinc, iron, manganese and copper, Soil Science Society of America Journal, 42, 421-428.

Nan Z.R., Zhao C.Y., Li J.J., Chen F.H. and Sun W. (2002) Relations between soil properties and selected heavy metal concentrations in spring wheat (Triticum aestivum L.) grown in contaminated soils, Water Air and Soil Pollution, 133, 205-213.

Olsen S.R. and Sommers L.E. (1982) Phosphorus, In: Methods of Soil Analysis Part 2 -Chemical and Microbiological Properties, Page A.L. et al. (eds.), ASA, SSSA, Madison, WI.

Panoras A.G., Hatzigiannakis E.G., Hlias A.K., Matsi Th., Arampatzis G.K., Barbouti S. and Kassioti S. (2005) Diachronic monitoring of irrigation soils for saline-sodic at the area of T.O.E.V. Halastra-Kalohori, Sindos, Thessaloniki (in Greek).

Rhoades J.D. (1996) Salinity: Electrical conductivity and total dissolved salts, In: Methods of Soil Analysis Part 3 - Chemical Methods, Sparks D.L. et al. (eds.), SSSA, ASA, Madison, WI.

Thomas G.W. (1982) Exchangeable cations, In: Methods of Soil Analysis Part 2 - Chemical and Microbiological Properties, Page A.L. et al. (eds.), ASA, SSSA, Madison, WI. 